\title{
Orthopedic abnormalities in an 8-year-old patient with Sanfilippo A disease: A case report
}

\section{Nieprawidłowości ortopedyczne u 8-letniej pacjentki z chorobą Sanfilippo A: opis przypadku}

\author{
Ryszard Tomaszewski1,3 (iD), Jerzy Pietruszewski² (iD), Anna Kostorz² (iD) \\ 1. Górnośląskie Centrum Zdrowia Dziecka, ul. Medyków 16, 40-752 Katowice, Oddział Chirurgii Urazowo-Ortopedycznej \\ 2. Górnośląskie Centrum Zdrowia Dziecka, ul. Medyków 16, 40-752 Katowice, Oddział Pediatrii i Neurologii Wieku Rozwojowego \\ 3. Uniwersytet Śląski w Katowicach, Wydział Nauk Ścisłych i Technicznych, Instytut Inżynierii Biomedycznej \\ DOI:10.20966/chn.2019.56.441
}

\section{STRESZCZENIE}

Choroba Sanfilippo A (mukopolisacharydoza III A) jest rzadką chorobą genetyczną charakteryzującą się postępującą neurodegeneracją spowodowaną wrodzonym niedoborem sulfatazy heparanu prowadzącym do niekontrolowanej akumulacji glikozaminoglikanów (siarczanu heparanu) w przestrzeni lizosomalnej i międzykomórkowej. Zaburzenie pojawia się po kilku latach prawidłowego rozwoju dziecka i jest związane ze zmianami w układzie nerwowym, żołądkowo-jelitowym, sercowo-naczyniowym, oddechowym, wzrokowym, słuchowym i mięśniowo-szkieletowym. Autorzy przedstawiają nieprawidłowości ortopedyczne u 8-letniej pacjentki z chorobą Sanfilippo A i omawiają rekomendacje dotyczące ortopedycznego leczenia deformacji szkieletowych w tej jednostce chorobowej. Prezentacja przypadku: Autorzy opisują 8-letnią dziewczynkę z chorobą Sanfilippo A, u której w wieku 3 lat ujawnity się pierwsze symptomy choroby. W wieku 8 lat, kiedy zaczęty się objawy ortopedyczne, w badaniu fizykalnym stwierdzano charakterystyczne dla mukopolisacharydozy cechy t.j.: pogrubiałe rysy twarzy, płaską nasadę nosa i suche, jasne włosy. W badaniu neurologicznym pacjentka prezentowała wielkogłowie, obniżone napięcie w osi głowa-tułów, a wzmożone w kończynach, chód samodzielny w nieprawidłowym wzorcu. Badanie ortopedyczne i badania dodatkowe ujawnity szpotawość stawów biodrowych, koślawość stawów kolanowych oraz tendencję do przykurczu ścięgien Achillesa. Wnioski: Choroba Sanfilippo A jest rzadką chorobą genetyczną - autosomalną recesywną - należącą do grupy lizosomalnych chorób spichrzeniowych. Po kilku latach od pierwszych objawów choroby ujawniaja się nieprawidłowości w układzie mięśniowo-szkieletowym. Najczęstsze zabiegi ortopedyczne w tej grupie pacjentów to uwolnienie cieśni nadgarstka i endoprotezowanie stawu biodrowego. W każdym przypadku należy indywidualnie rozważyć korzyści przekładające się na jakość życia chorego biorąc pod uwagę wysokie czynniki ryzyka podejmowanych interwencji operacyjnych i znieczulenia.

Słowa kluczowe: Zespół Sanfilippo, mukopolisacharydozy, nieprawidłowości ortopedyczne
ABSTRACT

Sanfilippo syndrome (mucopolysaccharidosis III - MPS III) is a rare genetic disease characterised by progressive neurodegeneration caused by uncontrolled lisosomal and intercellular space glycosaminoglycans (GAGs) accumulation. The disorder occurs after several years of proper child development and is related to changes in nervous, gastrointestinal, cardiovascular, respiratory, visual, auditory and musculoskeletal systems. The authors present orthopaedic abnormalities in an 8-year-old patient with Sanfilippo disease and discuss recommendation for medical intervention of skeletal deformations in patients suffering from Sanfilippo disease. Case presentation: an 8 -year-old girl with Sanfilippo disease is reported on. She was diagnosed at the age of 3 when the first abnormalities were revealed. At the age of 8 , when orthopaedic problems occurred the physical examination presented characteristic features of MPS such as thickened facial lines, flat base of the nose and dry, light hair. In neurological examination she presented macrocephaly, decreased axial muscle tone and increased circumferential muscle tone, independent but impaired gait pattern. Orthopaedics examination and diagnostic procedures revealed coxa vara, knee valgum and Achilles tendon contraction. Conclusion: Sanfilippo syndrome is a rare genetic - autosomal recessive - disease belonging to the group of Lysosomal Storage Disorders (LSDs). After several years after the first symptoms of the disease abnormalities in musculoskeletal system are revealed. The most common orthopaedic procedures in these patients are carpal tunnel release, trigger-finger release and hip replacement. In each case the patient 's $0 \mathrm{oL}$ and the high risk of surgery and anaesthesia should be balanced individually.

Keywords: Sanfilippo syndrome ,mucopolysaccharides, orthopaedic abnormalities

\section{ABBREVIATIONS}

MPS - mucopolysaccharidosis

GAG - glycosaminoglycans

SGSH - N-sulphoglucosamine sulphohydrolase

NAGLU $-\alpha$-N-acetylglucosaminidase

HGSNAT - heparan- $\alpha$-glucosaminide $\mathrm{N}$-acetyltransferase
GNS - N-acetylglucosamine-6-sulfatase

QoL - quality of life

\section{BACKGROUND}

Sanfilippo syndrome (mucopolysaccharidosis III) is a rare genetic - autosomal recessive -disease belonging to the 
group of Lysosomal Storage Disorders [1]. It is characterized by progressive neurodegeneration caused by congenital errors of metabolism - deficiencies in enzymes involved in the sequential degradation of mucopolysaccharides (glycosaminoglycans) [2]. Uncontrolled lisosomal and intercellulare space glycosaminoglycans' accumulation leads to progressive psychomotor retardation and characteristic dysmorphism caused by damage of nervous, gastrointestinal, cardiovascular, respiratory, visual, auditory and musculoskeletal systems. First symptoms of mucopolysaccharidosis III reveal after several (2-6) years of proper child development and progressively result in severe and rapid intellectual deterioration, behavioral disorders, dyskinesis, hyperkinesias, aggressiveness, sleeplessness, aphasia and seizures [3,4]. Each Sanfilippo type corresponds to lack of particular enzyme which is required to break down the heparansulfate. There are four subtypes of Sanfilippo syndrom recognized: mucopolysaccharidosis IIIA caused by inherited lack of N-sulphoglucosamine sulphohydrolase (SGSH), IIIB caused by inherited lack of $\alpha$-N-acetylglucosaminidase (NAGLU), IIIC caused by inherited lack of heparan- $\alpha$-glucosaminide $N$-acetyltransferase (HGSNAT) and IIID caused by inherited lack of $\mathrm{N}$-acetylglucosamine-6-sulfatase (GNS) [1,2]. Heparin sulfate is the glycosaminoglycan which cannot be decomposed in proper way, stores in lysosomes and tissues, particularly in the brain, what is responsible for symptoms in all subtypes of mucopolysaccharidosis III [2].

The authors present the case report of an 8-year-old patient with Sanfilippo A disease (mucopolysaccharidosis type IIIA). Prevalence of mucopolysaccharidosis III is calculated to 70.000 (mucopolysaccharidosis IIIA to 114.000). MPS IIIA is considered the most severe, although there is a great variation in the disease progression. Since mucopolysaccharidosis type III was first described by American physician Sylvester Sanfilippo in 1963 a large number of therapeutic method for effective treatment like substrate reduction therapy, enzyme replacement therapy, gene therapy or stem cell therapy has been investigated at pre-clinical or clinical trial stage but no commercially available research program can currently stop progression path in patients suffering from the disease $[5,6,7]$. The prognosis is unfavorable with death occurring, in most cases of type mucopolysaccharidosis IIIA, at the end of the second decade [8].

\section{Case presentation}

An 8-year-old girl with mucopolysaccharidosis IIIA, validated by insufficiency of N-sulphoglucosamine sulphohydrolase in leucocytes of blood test $(0,82 \mathrm{nmol} / \mathrm{mg}$ protein $/ 18$ hours [average: $4,1+/-1,4$ ], was admitted to the Department of Pediatric Trauma and Orthopedic Surgery to be qualified for tenotomy of the Achilles tendon. Her family, gestation and delivery history were negative. The diagnosis of Sanfilippo type A disorder was made in Department of Pediatric Neurology at the age of 3 years when the first symptoms of the disease occurred as psychomotor regress - the child started to lose the abilities and skills she had already acquired. Then she started to present loss of speech and mental retardation. Epilepsy (myoclonic and atonic attacks) occurred when the patient was 6 years old. She was also treated by a child psychiatrist, because of behavior disorders with hyperactivity and sleeplessness, with risperidone and melatonin, then, because of ineffectiveness - with clonazepamum and levomepromazine and finally - because of side effects - she was treated with levomepromazine and tiapride. On admission she was in good visual contact. Increased restlessness, dyskinesias and hyperkinesias attracted attention. In physical examination she presented characteristic for mucopolysaccharidosis features of dysmorphy like thickened facial lines, flat base of the nose and a dry, light hair. In neurological examination she presented macrocephaly, decreased axial muscle tone and increased circumferential muscle tone, independent but impaired gait pattern. In orthopedic examination she presented following range of movement: passive hip abduction was $35^{\circ}$, passive hip abduction was $30^{\circ}$, passive hip flexion was $140^{\circ}$, passive hip extension was $10^{\circ}$, passive hip internal rotation was $45^{\circ}$ and passive hip external rotation was $45^{\circ}$ (the patient walks with hip abduction about $25^{\circ}$ ). Range of movement in kneejoints was $0-140^{\circ}$; with knee valgum $15^{\circ}$, passive ankle dorsal flexion with the straightened knee was $10^{\circ}$ and passive ankle dorsal flexion with the flexed knee was $25^{\circ}$. Range of passive movement in elbow- joints was $0-140^{\circ}$ with bilateral deficit of supination of $15^{\circ}$. There was little static-dynamic disturbance in sitting position. In magnetic resonance imaging skull was distorted with its flattened bipedal and moderate widening of the interstitial. In central nervous system magnetic resonance imaging revealed generalised cortical atrophy with enlarged cerebral furrows, abnormal elevated signal in the T2 and FLAIR sequences of the inner capsule. The area of the elevated white matter signal in the FLAIR sequence was also visible around the ventricles and, to a lesser degree, subcortically in occipital lobes. There was, typical for mucopolysaccharidosis type III, minor volume of hills, numerous marked perivascular cavities within the white matter, mainly subcortically, corpus callosum with slightly reduced thickness. Magnetic resonance imaging also showed increased pituitary size to $11 \mathrm{~mm}$. Summarizing, the magnetic resonance imaging changes corresponded to changes which are typical for mucopolysaccharidosis type III (Fig. 1,2). In the ultrasonography of abdomen hepatosplenomegaly was revealed. X-rays showed the bilateral coxa vara (with angle about 105 degree) and knee valgum (Fig. 3,4). After taking into account all the advantages and disadvantages and literature recommendation, the patient was not qualified for tenotomy of the Achilles tendon because of a moderate degree of contraction not significantly affecting the gait, progressive character of the disease and high risk of surgery and anesthesia. The patient was also consulted by neurosurgeon for intratecal therapy with baclofen but she was disqualified because of changeable and minor level of spasticity. We decided to continue the clinical observation and the periodic radiological control.

\section{DISCUSSION}

Orthopedic abnormalities are observed in all types of mucopolysaccharidosis (dysostosis multiplex) but they are characterized by great phenotypic variety [9]. The most common types are cervical stenosis and instability, cord compression, thoracolumbar kyphosis, significant scoliosis with thora- 


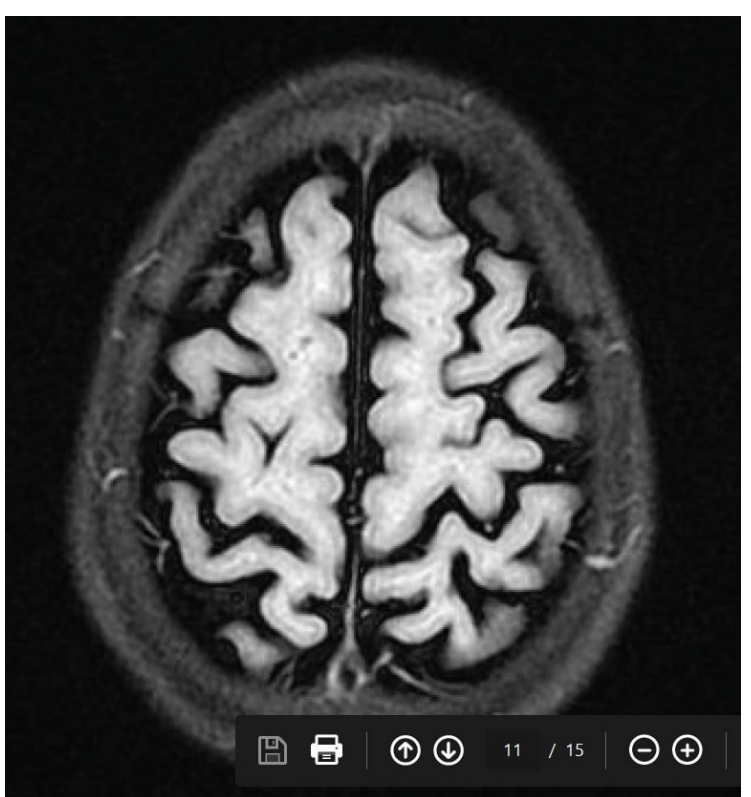

Fig. 1. Neuroimaging (magnetic resonance imaging) - typical changes for mucopolysaccharidosis type III

Ryc. 1. Neuroobrazowanie (magnetyczny rezonas jądrowy) typowe zmiany dla mukopolisacharydozy typu III

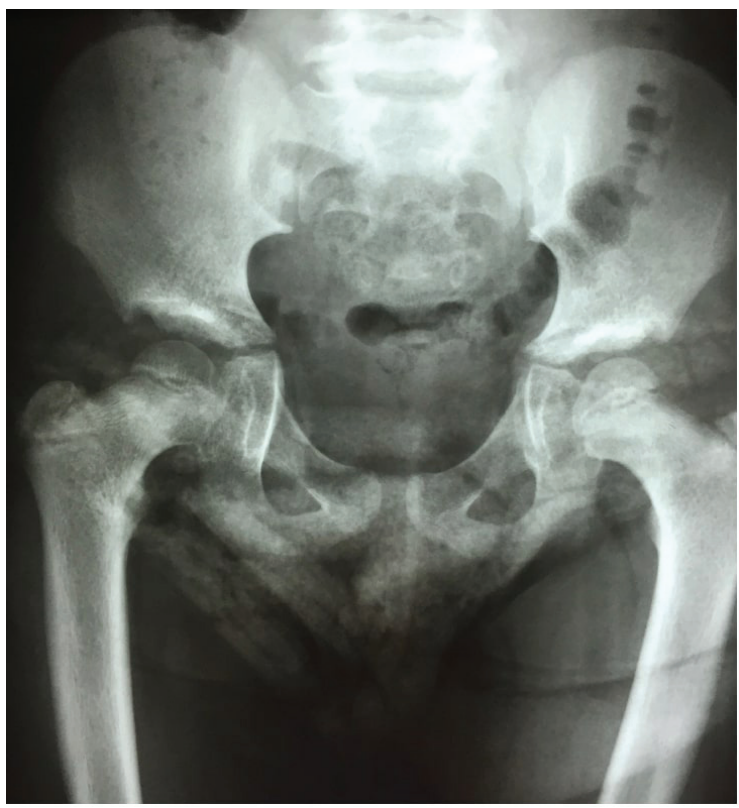

Fig. 3. X-ray - the bilateral coxa vara

Ryc. 3. RTG - obustronna szpotawość stawów biodrowych

columbar kyphosis and dysplastic/hypoplastic/misshapen vertebral bodies, hip dysplasia, osteonecrosis of the femoral heads, genu valgum, carpal tunnel syndrome, short stature, joint and bones deformations and abnormalities including join restriction or hypermobility [10]. Join pain is a common musculosceletal manifestation in patients with Sanfilippo disease. The orthopedics effects on skeletal anatomy of mucopolysaccharidosis type III A are less severe than in others mucopolysaccharidosis [9]. However particularly the spine and the hips get involved in mucopolysaccharidosis III A. According to literature in Sanfilippo disease hip dysplasia,

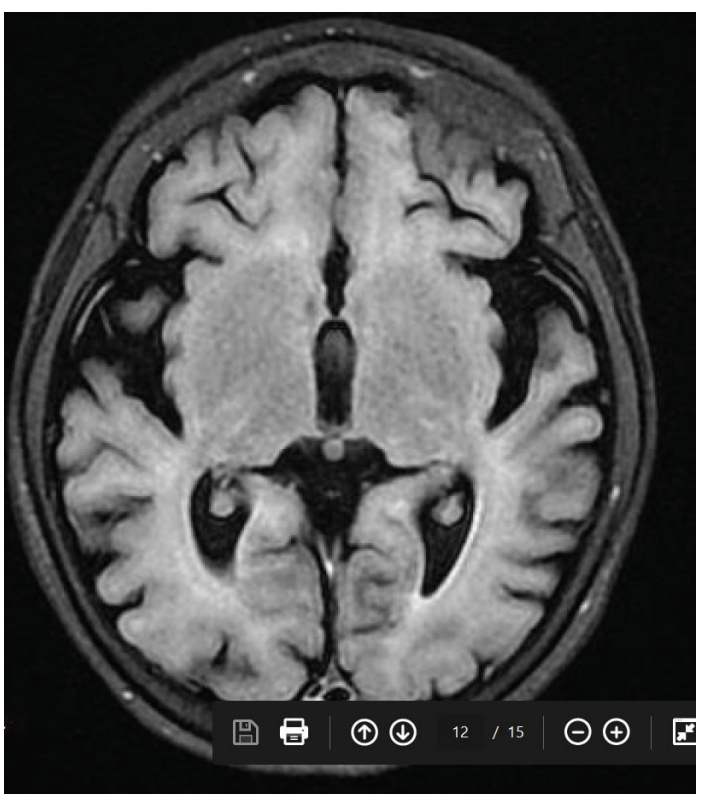

Fig. 2. Neuroimaging (magnetic resonance imaging) - typical changes for mucopolysaccharidosis type III

Ryc. 2. Neuroobrazowanie (magnetyczny rezonas jądrowy) typowe zmiany dla mukopolisacharydozy typu III

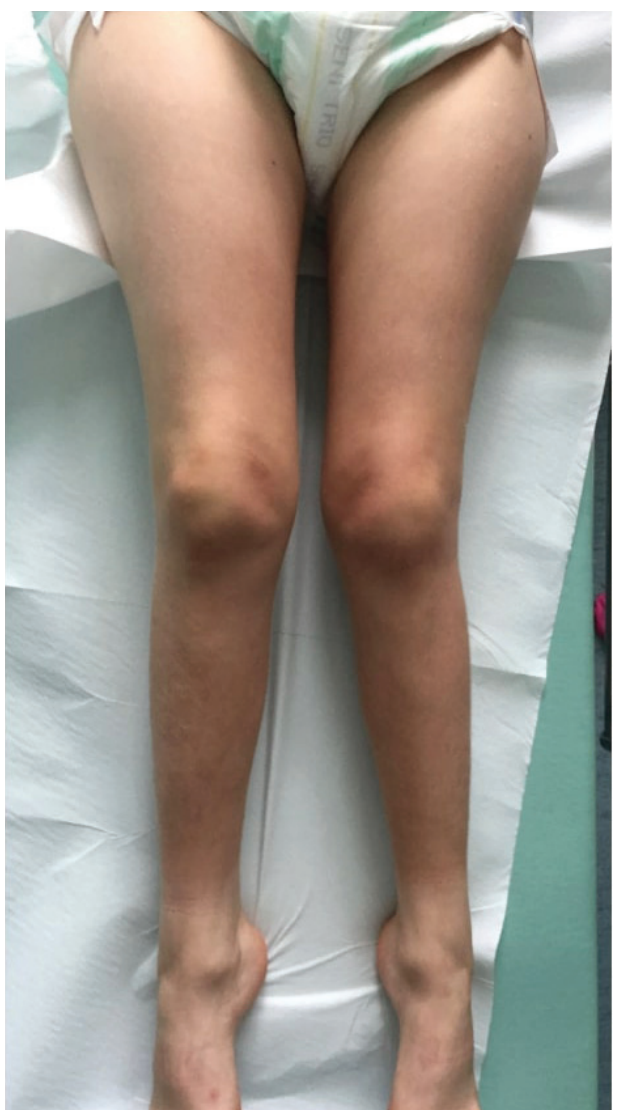

Fig. 4. Knee valgum

Ryc. 4. Koślawość stawu kolanowego

progressive scoliosis and genu valgum are the most frequent [10]. The scoliosis, kyphosis occur in about $50 \%$ patients but the severe spine deformation is rare. The treatment of the spine deformation considers the rehabilitation, possibly brace, and in severe cases, the surgery. It was described 
also the L1 hypoplasia in mucopolysaccharidosis III A but frequently without spine deformities. The cervical spine instability and stenosis which is frequently present in patients with mucopolysaccharidosis, was not established in mucopolysaccharidosis III A [9]. The hips deformities include the avascular femoral head necrosis and the hip dysplasia. Most often pain is the first sign, but the painless patients were also described. The femoral head necrosis is slow with radiological signs of resorption and fragmentation which is caused by the storage of the glycosaminoglycan and it leads to the cartilage apoptosis [10]. The surgical treatment of the hip deformities in mucopolysaccharidosis III A is recommended with some caution but some authors advocate hip prothesis in patients with hip dysplasia accompanying the femoral head necrosis [11]. The small series show good prothesis follow up but the periprosthetic fracture was also presented. The indication for femoral osteotomy in acetabular dysplasia is rare according to many authors [10]. Our patient presented the coxa vara without the acetabular dysplasia, we also did not find the surgical indication but it seems that the periodic radiological hip control is recommended in mucopolysaccharidosis III. Knee valgum deformities are well described in mucopolysaccharidosis but in mucopolysaccharidosis IIIA there is a small knee valgum deformity with low progressive evolution, the tibia did not require the surgical treatment (epiphysiodesis or osteotomy) [9]. As our patient presented the moderate knee valgum, we decided to continue the observation considering the slow progression of the deformity. The equinus and equinovarus foot deformities are rare and the clinical symptoms are minor without surgical indications [11]. Which we also found in the case of our patient and which caused the absence of qualification for surgical treatment at the moment. The most common cause of the carpal syndrome in children is mucopolysaccharidosis. As the symptoms like pain or neurological deficits are very minimal therefore the screening for nerve condition is recommended. The carpal syndrome surgery in mucopolysaccharidosis III requires not only the carpal tunnel release but also excision of the abundant tenosynovium [12]. The trigger finger frequently accompanies the mucopolysaccharidosis and requires the surgical releases [10]. The most often operative indications in mucopolysaccharidosis III include carpal tunnel syndrome, trigger digits and progressive scoliosis of large magnitude. But when patients with mucopolysaccharidosis III undergo surgical procedures, often intended to improve their quality of life, they have serious anaesthetic difficulties like difficulty of airway management due to accumulation of heparin sulfate in the tissues surrounding the upper respiratory tract and skeleton malformation of mouth, throat and cervical spine, due to skeletal, neurologic and cardio-respiratory alterations. There is limited bibliography of orthopaedic procedures in these patients but the most frequent ones are carpal tunnel re- lease, trigger-finger release and hip replacement in children and adolescents $[10,11]$ whereas in adult patients, due to progressive degenerative changes in the joints, all endoprosthetic procedures are performed [12]. Because of the high surgical (anesthetic) risk and uncertain long-term benefits due to progressive character of the disease, surgery is only recommended when pain is at rest, limits everyday activities, is not relieved with anti-inflammatory drugs, physical therapy or walking support and joint stiffness limits motion in daily routine $[13,14]$.

\section{CONCLUSION}

In summary, the orthopedics effects on skeletal anatomy of mucopolysaccharidosis type III A are less severe than in others mucopolysaccharidosis. Operative indications include persistent pain and limited motion caused by carpal tunnel syndrome, trigger digits and progressive scoliosis of large magnitude. In each case it should be balanced individually between the patient's quality of life and the risk of surgery and anesthesia.

\section{REFERENCES}

[1] Bodamer 0.A., Guigliani R., Wood T.: The laboratory diagnosis of mucopolysaccharidosis III (Sanfilippo syndrome). A changing landscape. Mol Genet Metab 2014; 113: 34-41.

[2] Yogalingam G., Hopwood J.J.: Molecular genetics of mucopolysaccharidosis type IIIA and IIIB: diagnostic, clinical and biological implications. Hum Mutat 2001; 18: 264-281.

[3] Wijburg F.A., Węgrzyn G., Burton B.K., et. al.: Mucopolysaccharidosis type III (Sanfilippo syndrome) and misdiagnosis of idiopathic developmental delay, attention deficit/hyperactivity disorder or autism spectrum dis order. Acta Paediatr 2013; 102: 462-470.

[4] Valstar M.J., Marchal J.P., Grootenhuis M., et. al.: Cognitive development in patients with mucopolysaccharidosis type III (Sanfilippo syndrome). Orphanet J Rare Dis 2011; 6: 43.

[5] Dickson P.I., Chen A.H.: Intrathecal enzyme replacement therapy for mucopolysaccharidosis I: translating success in animal models to patients. Curr Pharm Biotechno 2011; 12: 946-955.

[6] Gilkes J.A., Heldermon C.D.: Mucopolysaccharidosis III (Sanfilippo Syndrome) - disease presentation and experimental therapies. PER 2014; 12(Suppl. 1): 133-140.

[7] Aoyagi-Scharber M., Crippen-Harmon D., Lawrence R., et. al.: Clearance of Heparan Sulfate and Attenuation of CNS Pathology by Intracerebroventricular BMN 250 in Sanfilippo Type B Mice. Mol Ther-Meth Clin D 2017; 6: 43-53.

[8] Mitchell J., Berger K.I., Borgo A., et. al.: Unique medical issues in adult patients with mucopolysaccharidoses. Eur J Inern Med 2016; 34: 2-10.

[9] White K.K., Karol L.A., White D.R., et. al.: Musculoskeletal manifestations of Sanfilippo Syndrome (mucopolysaccharidosis type III). J Pediatr Orthoped 2011; 31: 594-598.

[10] White K.K., Harmatz P.: Orthopedic management of mucopolysaccharide disease. J Pediatr Rehabil Med 2010; 3: 47-56.

[11] Valayannopoulos V., Wijburg F.A.: Therapy for the mucopolysaccharidoses. Rheumatology (Oxford) 2011; 50(Suppl. 5): 49-59.

[12] Esmee Oussoren' David van Eerd' Elaine Murphy et al . Mucolipidosis type III, a series of adult patients. Journal of Inherited Metabolic Disease (2018) 41:839-848.

[13] White K., Kim T., Neufeld J.A.: Clinical assessment and treatment of carpal tunnel syndrome in the mucopolysaccharidoses. J Pediatr Rehabil Med 2010; 3: 57-62.

[14] Muhlebach M.S., Wooten W., Muenzer J.: Respiratory manifestations in mucopolysaccharidoses. Paediatr Respir Rev 2011; 12: 133-138.

\section{Corresponding author:}

Ryszard Tomaszewski, Górnośląskie Centrum Zdrowia Dziecka, ul. Medyków 16, 40-752 Katowice, Oddział Chirurgii Urazowo-Ortopedycznej, tomaszewskir@gmail.com 